\title{
A MATHEMATICAL MODEL FOR THE TEMPERATURE FIELD IN THE ABSORBER OF A NEW TYPE SOLAR COLLECTOR
}

\author{
P. Shipkov ${ }^{1}$, V. Barkans ${ }^{2}$, M. Vanags ${ }^{1}$, L. Vasilevska ${ }^{1}$ \\ ${ }^{1}$ Institute of Physical Energetics, \\ 21 Aizkraukles Str., Riga, LV-1006, LATVIA, \\ email: shipkovs@edi.lv \\ ${ }^{2}$ Latvian Maritime Academy, \\ 5B Flotes Str., Riga, LV-1016, LATVIA, \\ email: voldemars.barkans@inbox.lv
}

\begin{abstract}
The temperature field problem described in the paper is analytically solved for the absorber of a new type solar collector. The absorber consists of two plates, one of them being flat and placed on top of the other plate made with a square profile. The temperature field is calculated for four areas using the Laplace equation under stationary conditions. For each area the boundary conditions are written and the Laplace equation solved. The resultant temperature fields are found for each area separately.
\end{abstract}

\section{INTRODUCTION}

Solar collectors are devices using solar radiation for heating water. Such a collector is designed as a box which is thermo-insulated from the bottom with a layer of rock wool (more typically) or of some other material. On the thermoinsulating layer an absorber is placed. A typical absorber presents a copper sheet to which a copper pipe is serpentine-wise fastened. In the pipe a heat carrier (usually $40 \%$ aqueous solution of propylene-glycol) flows. The box is covered with protective glass. When the installation is tilted against the sun, the absorber is absorbing sunlight and heats up. By thermal conduction the heat from the absorber is transferred to the carrier, which, by a pump or by means of convection, is fed to the tank for storing hot water, where this heat is given up to the water. Already in earlier works of the authors [1-3] the mathematical models were presented which described the heat conduction process in the absorber of a flat-plate collector. In these works, the temperature field was obtained both for the stationary and the nonstationary process. The absorbers calculated in the mentioned works possess a specific property in the case of a long (up to $10 \mathrm{~cm}$ ) heat conduction path. This property was the main reason for choosing copper as the absorber's material rather good heat conductor; this though cannot be said about its price, since a copper absorber is one of the most expensive components of a solar collector. Using two metallic plates, one of them flat while the other perforated, and stacking them together, we obtain a design suitable for the solar collector's absorber whose cross-section is shown in Fig. 1. Through the perforated spaces a liquid heat carrier 
can circulate. The present work describes mathematically the temperature field in the absorber consisting of a flat metallic plate over which another metallic plate with a pressed square relief is laid.

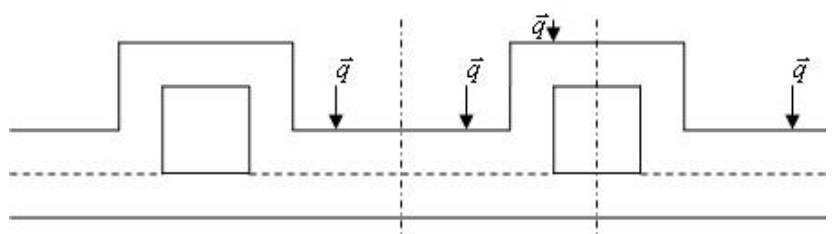

Fig. 1. Cross-section of the absorber plate: $q$ is the solar radiation density.

\section{A MATHEMATICAL MODEL OF THE PROBLEM}

We will consider the cross-section of a collector's plate (Fig. 1), which is perpendicular to the axis of the pipes with liquid. The pipes are not circular but have a square cross-section. In one span (chosen from those shown in Fig. 1) we will fix a relevant frame of reference. This span of cross-section will conventionally be divided into four parts (subsections): D1, D2, D3, D4.

Considering the process stationary, the temperature field in the Descartes coordinate system is described by the Laplace equation [1]:

$$
\frac{\partial^{2} \Theta}{\partial \xi^{2}}+\frac{\partial^{2} \Theta}{\partial \eta^{2}}=0 .
$$

Equation (1) is presented in dimensionless quantities whose physical sense has not yet been disclosed. The correlation of these quantities with real ones is shown in Fig. 2, where the absorber's span divided into four parts could be seen. For each part the following is valid:

$$
\Theta(\xi, \eta)=\left\{\begin{array}{l}
\Theta_{1}(\xi, \eta), \text { where }(\xi, \eta) \in D_{1}\left\{\begin{array}{c}
0 \leq \xi \leq \xi_{1} ; \\
0 \leq \eta \leq 2 \eta_{0} ;
\end{array}\right. \\
\Theta_{2}(\xi, \eta), \text { where }(\xi, \eta) \in D_{2}\left\{\begin{array}{l}
\xi_{1} \leq \xi \leq \xi_{2} \\
0 \leq \eta \leq \eta_{2}
\end{array} ;\right. \\
\Theta_{3}(\xi, \eta), \text { where }(\xi, \eta) \in D_{3}\left\{\begin{array}{c}
\xi_{2} \leq \xi \leq 1 ; \\
0 \leq \eta \leq \eta_{0} ;
\end{array}\right. \\
\Theta_{4}(\xi, \eta), \text { where }(\xi, \eta) \in D_{4}\left\{\begin{array}{c}
\xi_{2} \leq \xi \leq 1 ; \\
\eta_{1} \leq \eta \leq \eta_{2} .
\end{array}\right.
\end{array}\right.
$$

Here $\Theta_{1}=\frac{T_{1}}{T_{0}}, \Theta_{2}=\frac{T_{2}}{T_{0}}, \Theta_{3}=\frac{T_{3}}{T_{0}}, \Theta_{4}=\frac{T_{4}}{T_{0}}$ are the dimensionless temperatures with the initial temperature $T_{0}(K)$, and, respectively,

$T_{1}, T_{2}, T_{3}$ and $T_{4}(K)-$ the temperatures in each given part: $\mathrm{D}_{1}, \mathrm{D}_{2}, \mathrm{D}_{3}$ and $\mathrm{D}_{4}$. 


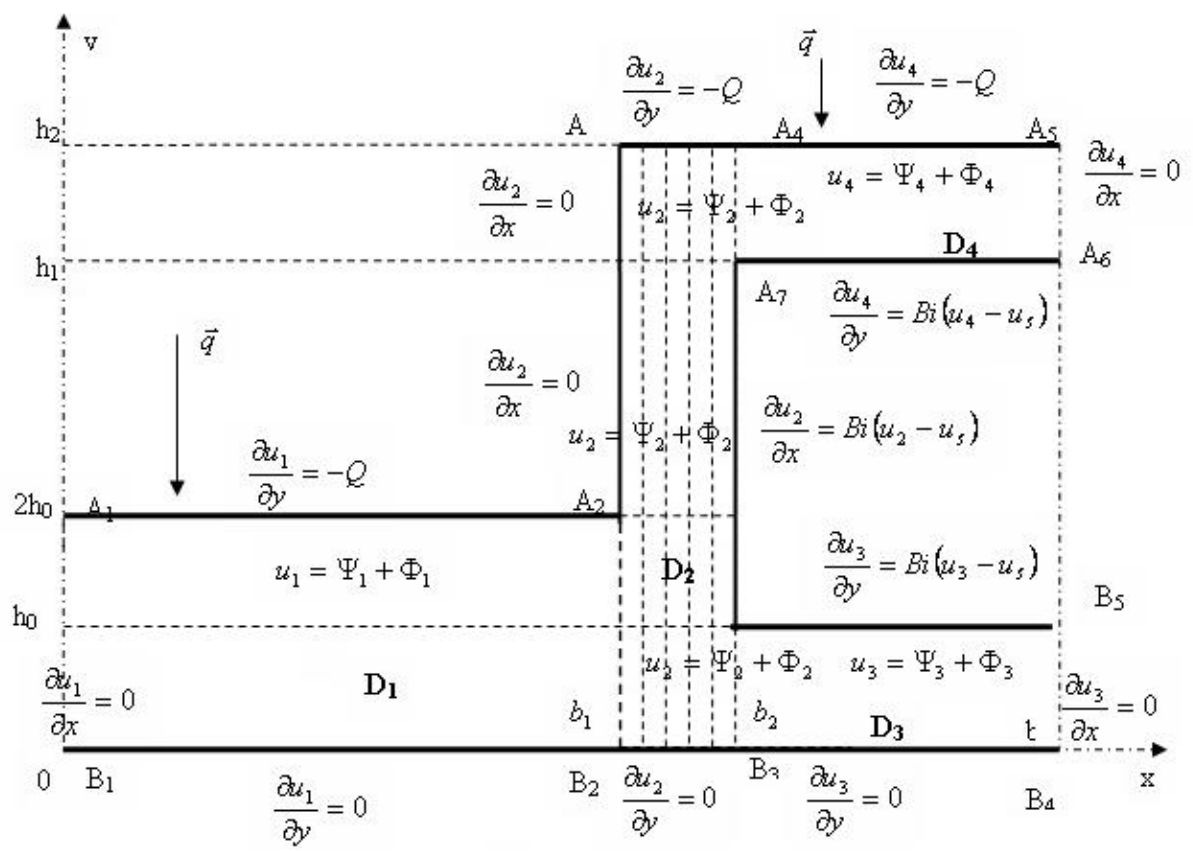

Fig. 2. The area of the solar collector's absorber in which the temperature field is calculated

The dimensionless coordinates are expressed by the formulas:

$$
\begin{aligned}
& \xi=\frac{x}{b}, \quad \xi_{1}=\frac{b_{1}}{b}, \quad \xi_{2}=\frac{b_{2}}{b} \quad \text { if }\left(\begin{array}{l}
0 \leq x \leq b ; \\
0 \leq \xi \leq 1 ;
\end{array}\right) \text {, and } \\
& \eta=\frac{y}{b}, \quad \eta_{0}=\frac{h_{0}}{b}, \quad \eta_{1}=\frac{h_{1}}{b}, \quad \eta_{2}=\frac{h_{2}}{b} \quad \text { if }\left(\begin{array}{l}
0 \leq y \leq h_{2} ; \\
0 \leq \eta \leq \eta_{2}
\end{array}\right) .
\end{aligned}
$$

The parameters $Q$ and $B i$ are expressed in the following manner:

$$
Q=\frac{q}{\lambda} \frac{b}{T_{0}} \text { and } B i=\frac{\alpha}{\lambda} b,
$$

where $2 b$ is the distance between the axes of the pipes, $\mathrm{m}$;

$2 h_{0}$ is the thickness of the collector plate, $\mathrm{m}$;

$q$ is the density of solar heat flow, $\mathrm{W} / \mathrm{m}^{2}$;

$\lambda$ is the heat conductivity of the collector plate, $\mathrm{W} /(\mathrm{m} \cdot \mathrm{K})$;

$\alpha$ is the coefficient of surface convective heat transfer, $\mathrm{W} /\left(\mathrm{m}^{2} \cdot \mathrm{K}\right)$.

To write down the boundary conditions for solving Eq. (1), we will assume that the bottom surface of the absorber at $\eta=0$ is ideally insulated. Then the heat exchange on this surface is equal to zero, i.e.:

$$
\begin{aligned}
& \left.\frac{\partial \Theta_{1}}{\partial \eta}\right|_{\eta=0}=\left.0 \quad \frac{\partial \Theta_{2}}{\partial \eta}\right|_{\eta=0}=\left.0 \quad \frac{\partial \Theta_{3}}{\partial \eta}\right|_{\eta=0}=0, \\
& 0 \leq \xi \leq \xi_{1}, \quad \xi_{1} \leq \xi \leq \xi_{2}, \quad \xi_{2} \leq \xi \leq 1 .
\end{aligned}
$$


The top surface of this section is irradiated by the sun, therefore:

$$
\begin{aligned}
& \left.\frac{\partial \Theta_{1}}{\partial \eta}\right|_{\eta=2 \eta_{0}}=-\Omega,\left.\quad \frac{\partial \Theta_{2}}{\partial \eta}\right|_{\eta=\eta_{2}}=-\Omega,\left.\quad \frac{\partial \Theta_{4}}{\partial \eta}\right|_{\eta=\eta_{2}}=-\Omega, \\
& 0 \leq \xi \leq \xi_{1}, \quad \xi_{1} \leq \xi \leq \xi_{2}, \quad \xi_{2} \leq \xi \leq 1 .
\end{aligned}
$$

On the axis of symmetry the derivatives of temperature field with respect to coordinates are equal to zero:

$$
\begin{aligned}
& \left.\frac{\partial \Theta_{1}}{\partial \xi}\right|_{\xi=0}=0,\left.\quad \frac{\partial \Theta_{3}}{\partial \xi}\right|_{\xi=1}=0,\left.\quad \frac{\partial \Theta_{4}}{\partial \xi}\right|_{\xi=1}=0, \\
& 0 \leq \eta \leq 2 \eta_{0}, \quad 0 \leq \eta \leq \eta_{0}, \quad \eta_{1} \leq \eta \leq \eta_{2} .
\end{aligned}
$$
therefore:

On the common section boundaries the temperatures are to be equal,

$$
\begin{aligned}
& \left.\Theta_{1}\right|_{\xi=\xi_{1}}=\left.\Theta_{2}\right|_{\xi=\xi_{1}},\left.\quad \Theta_{2}\right|_{\xi=\xi_{2}}=\left.\Theta_{3}\right|_{\xi=\xi_{2}},\left.\quad \Theta_{2}\right|_{\xi=\xi_{2}}=\left.\Theta_{4}\right|_{\xi=\xi_{2}}, \\
& 0 \leq \eta \leq 2 \eta_{0}, \quad 0 \leq \eta \leq \eta_{0}, \quad \eta_{1} \leq \eta \leq \eta_{2} .
\end{aligned}
$$
equations:

On the section boundaries the heat exchange is described by the following

$$
\begin{aligned}
& \left.\frac{\partial \Theta_{1}}{\partial \xi}\right|_{\xi=\xi_{1}}=Q \frac{\xi_{1}}{2 \eta_{0}}, \quad 0 \leq \eta \leq 2 \eta_{0} ; \\
& \left.\frac{\partial \Theta_{2}}{\partial \xi}\right|_{\xi=\xi_{1}}=\left\{\begin{array}{llc}
\left.\frac{\partial \Theta_{1}}{\partial \xi}\right|_{\xi=\xi_{1}}, & \text { if } & 0 \leq \eta \leq 2 \eta_{0} \\
0, & \text { if } & 2 \eta_{0} \leq \eta \leq \eta_{2} .
\end{array}\right. \\
& \left.\frac{\partial \Theta_{2}}{\partial \xi}\right|_{\xi=\xi_{2}}= \begin{cases}\left.\frac{\partial \Theta_{3}}{\partial \xi}\right|_{\xi=\xi_{2}}, & \text { if } 0 \leq \eta \leq \eta_{0} ; \\
\left.B i\left(\Theta_{2}-\Theta_{0}\right)\right|_{\xi=\xi_{2}}, & \text { if } \eta_{0} \leq \eta \leq \eta_{1}\end{cases} \\
& \left.\frac{\partial \Theta_{3}}{\partial \eta}\right|_{\eta=\eta_{0}}=\left.B i\left(\Theta_{3}-\Theta_{0}\right)\right|_{\eta=\eta_{0}}, \quad \xi_{2} \leq \xi \leq 1 ; \\
& \left.\frac{\partial \Theta_{4}}{\partial \eta}\right|_{\eta=\eta_{1}}=\left.B i\left(\Theta_{4}-\Theta_{0}\right)\right|_{\eta=\eta_{1}}, \quad \xi_{2} \leq \xi \leq 1 .
\end{aligned}
$$




\section{PROBLEM SOLUTION}

To find the temperature field in subsection $D_{1}$ the function $\Theta_{1}$ is written in the form of a quadratic function:

$$
\Theta_{1}(\xi, \eta)=A\left(\xi^{2}-\eta^{2}\right)+C \xi \eta+D \xi+E \eta+F
$$

which satisfies Laplace's equation (1). Applying boundary conditions (3)-(6), we obtain the dimensionless temperature field in subsection $\mathrm{D}_{1}$ :

$$
\Theta_{1}(\xi, \eta)=\frac{Q}{4 \eta_{0}}\left(\xi^{2}-\eta^{2}\right)+F,
$$

where $F=1+Q \eta_{0}$.

For solving the temperature field problem, the mathematically-physical methods described in [4-8] are applied. Function $\Theta_{2}$ is divided into two components:

$$
\Theta_{2}=\Phi_{2}+\Psi_{2},
$$

both satisfying the Laplace equations:

$$
\Delta \Phi_{2}=0 ; \quad \Delta \Psi_{2}=0
$$

and the corresponding boundary conditions that are written for both the functions:

$$
\begin{array}{ll}
\left.\frac{\partial \Phi_{2}}{\partial \eta}\right|_{\eta=0}=0 ; & \left.\frac{\partial \Phi_{2}}{\partial \eta}\right|_{\eta=\eta_{2}}=0 ; \quad \xi_{1} \leq \xi \leq \xi_{2} ; \\
\left.\frac{\partial \Psi_{2}}{\partial \eta}\right|_{\eta=0}=0 ; & \xi_{1} \leq \xi \leq \xi_{2} ; \\
\left.\Psi_{2}\right|_{\xi=\xi_{2}}=0 ; & \left.\Psi_{2}\right|_{\xi=\xi_{1}}=0 ; \quad 0 \leq \eta \leq \eta_{2} .
\end{array}
$$

Using the Fourier method of variable/argument separation, we obtain the temperature field in subsection $\mathrm{D}_{2}$ as

$$
\begin{gathered}
\Theta_{2}(\xi, \eta)=\frac{1}{2}\left(a_{2,0}+a_{2,1} \xi\right)+\sum_{k=1}^{\infty}\left(a_{2, k} \operatorname{ch} \lambda_{2, k} \xi+b_{2, k} \operatorname{sh} \lambda_{2, k} \xi\right) \cos \lambda_{2, k} \eta+ \\
+\frac{2 Q}{\xi_{2}-\xi_{1}} \sum_{k=1}^{\infty} \frac{1-(-1)^{k}}{\mu_{2, k}^{2}} \frac{\operatorname{ch} \mu_{2, k} \eta}{\operatorname{sh} \mu_{2, k} \eta_{2}} \cos \mu_{2, k}\left(\xi-\xi_{2}\right)
\end{gathered}
$$

where specific values are expressed by the formulas:

$$
\lambda_{2, k}=\frac{k \pi}{\eta_{2}} ; \quad \mu_{2, k}=\frac{k \pi}{\xi_{2}-\xi_{1}} ; \quad k=1,2,3, \ldots
$$


Similar to subsection $\mathrm{D}_{2}$, the temperature field is obtained also in $\mathrm{D}_{3}$ and $\mathrm{D}_{4}$ subsections. Here we will only write down the temperature fields in corresponding subsections omitting the solution procedure. Therefore, in subsection $\mathrm{D}_{3}$ the temperature field will be:

$$
\begin{gathered}
\Theta_{3}(\xi, \eta)=\frac{a_{3,0}}{2}+\sum_{k=1}^{\infty} a_{3, k} \operatorname{ch} \lambda_{3, k}(\xi-1) \cos \lambda_{3, k} \eta+ \\
+\sum_{k=1}^{\infty} c_{3, k} \operatorname{ch} \mu_{3, k} \eta \cos \mu_{3, k}(\xi-1)
\end{gathered}
$$

with the specific values:

$$
\lambda_{3, k}=\frac{k \pi}{\eta_{0}} ; \quad \mu_{3, k}=\frac{k \pi}{1-\xi_{2}} ; \quad k=1,2,3, \ldots
$$

In turn, in subsection $\mathrm{D}_{4}$ the temperature field is:

$$
\begin{gathered}
\Theta_{4}(\xi, \eta)=\frac{a_{4,0}}{2}-Q \eta+\sum_{k=1}^{\infty} a_{4, k} \operatorname{ch} \lambda_{4, k}(\xi-1) \cos \lambda_{4, k}\left(\eta-\eta_{2}\right)+ \\
+\sum_{k=1}^{\infty} b_{4, k} \operatorname{ch} \mu_{4, k}\left(\eta-\eta_{2}\right) \cos \mu_{4, k}(\xi-1)
\end{gathered}
$$

with the specific values:

$$
\lambda_{4, k}=\frac{k \pi}{\eta_{2}-\eta_{1}} ; \quad \mu_{4, k}=\mu_{3, k}=\frac{k \pi}{1-\xi_{2}} ; \quad k=1,2,3, \ldots
$$

Using the equality of heat flows and temperatures on the common boundaries $\xi=\xi_{1}$ of subsections $\mathrm{D}_{1}$ and $\mathrm{D}_{2}$, we obtain the equations for finding the unknown coefficients.

\section{CONCLUSION}

The analytical solution has been found for the temperature field in the absorber of a new type solar collector consisting of two plates: one of them flat and the other (laid over the former) - perforated with square ribs. The temperature field is calculated in four subsections using the Laplace equation under stationary conditions. For each section the boundary conditions are formulated, and the Laplace equation is solved. As a result, the temperature field problem has been solved for each subsection separately.

\section{REFERENCES}

1. Temkins, A., Barkans, V., Shipkovs, P., Vanags, M., Lebedeva, K., \& Shipkovs, J. (2005). Heat conduction process on plane surface of a solar collector absorber: the mathematical description. Latv. J. Phys. Tec. Sci., 6, 3-15.

2. Barkāns, V., Temkins, A., Shipkovs, P., Vanags, M., \& Lebedeva, K. (2007). Nestacionāra siltumvadīšanas procesa matemātisks apraksts saules kolektorā. Latvijas Jūras 
Akadēmija, 9. Starptautiskā konference, Ūdens Transports un Infrastruktūra, 214-225 (in Latvian).

3. Barkāns, V., Temkins, A., Shipkovs, P., Kaškarova G., Vanags, M., Lebedeva, K., \& Shipkovs, J. (2006). Plakanas virsmas saules kolektora fizikāli matemātiskie modeḷi. Latvijas Jūras Akadēmija, 8. Starptautiskā konference, Ūdens transports un infrastruktūra, 130-137 (in Latvian).

4. Исаченко, В.П., Осипова, В.А., \& Сукомел, А.С. (1969). Теплопередача. М.: Энергия.

5. Riekstin̦š, E. (1969). Matematiskās fizikas metodes. Rīga: Zvaigzne.

6. Кошляков, Н.С., Глинер, Э.Б., \& Смирнов, М.М. (1962). Основные дифференциальные уравнения математической физики. Москва: Физматгиз.

7. Тихонов, А.Н., \& Самарский, А.А. (1956). Уравнения математической физики. М.: Наука.

8. Прудников, А.П., Бычков, Ю.А., \& Маричев, О.И. (1983). Интеграль и ряды. Специильные функции. М.: Наука.

\title{
JAUNA TIPA SAULES KOLEKTORA ABSORBERA TEMPERATŪRAS LAUKA MATEMĀTISKS MODELIS
}

\author{
P. Šipkovs, V. Barkāns, M. Vanags, L. Vasil̨evska
}

\section{Kopsavilkums}

Darbā tiek analītiski atrisināts temperatūras lauks jauna tipa saules kolektora absorberī, kura konstrukcija sastāv no divām plāksnēm. Viena plāksne ir plakana, un tai virsū piestiprināta otra plāksne, kas ir perforēta ar kvadrātiskiem izciḷniem. Temperatūras lauks tiek rēķināts četros apgabalos, izmantojot Laplasa vienādojumu stacionāros apstākḷos. Tiek uzrakstîti robežnosacījumi katrā apgabalā un atrisināts Laplasa vienādojums. Rezultātā iegūts temperatūras lauks katrā apgabalā atsevišķi.

11.08.2010. 